\title{
Ophryoglena hemophaga n. sp. (Ciliophora: Ophryoglenidae): a parasite of the digestive gland of zebra mussels Dreissena polymorpha
}

\author{
Daniel P. Molloy ${ }^{1, *}$, Denis H. Lynn ${ }^{2}$, Laure Giamberini ${ }^{3}$ \\ ${ }^{1}$ New York State Museum, The State Education Department, Cultural Education Center, Albany, New York 12230, USA \\ ${ }^{2}$ Department of Zoology, University of Guelph, Guelph, Ontario N1G 2W1, Canada \\ ${ }^{3}$ Laboratoire Ecotoxicité et Santé Environnementale, CNRS UMR 7146, Université Paul Verlaine-Metz, Campus Bridoux, \\ rue du Général Délestraint, 57070 Metz Cedex, France
}

\begin{abstract}
Ophryoglena hemophaga n. sp. is described from a freshwater Dreissena polymorpha population in the Rhine delta of the Netherlands. This is the first ophryoglenine species (order Hymenostomatida, suborder Ophryoglenina) recorded as a molluscan parasite. As is typical of ciliates in the suborder Ophryoglenina, O. hemophaga exhibits a polymorphic life history with cystment and reproduction by palintomy. Trophonts were observed within digestive gland lumina, and zebra mussel hemocytes were present in some of their digestive vacuoles. The presence of a single, longitudinal tract of multiple contractile vacuoles represents its most unique feature and distinguishes it from all other described Ophryoglena spp. The number of somatic kineties of O. hemophaga (range 50 to 62) is also a distinguishing feature, since it is the lowest described from any Ophryoglena sp. Other characteristics of this species include: ovoid to elongate trophonts 96 to $288 \mu \mathrm{m}$ in length, with an elongate macronucleus 41 to $65 \mu \mathrm{m}$ in length; tomonts 50 to $150 \mu \mathrm{m}$ in diameter producing a clear mucous cyst envelope, whose thickness is approximately half of the tomont diameter; elongated theronts 96 to $131 \mu \mathrm{m}$ in length which emerge after 1 to 3 cell divisions taking 36 to $48 \mathrm{~h}$ at $20 \pm 3^{\circ} \mathrm{C}$. Protomonts and theronts are, respectively, negatively and positively phototactic - characteristics that likely aid in maintenance of infection in zebra mussel populations.
\end{abstract}

KEY WORDS: Contractile vacuoles · Trophont · Tomont · Theront · Zebra mussel · Palintomy • Phototaxis

\section{INTRODUCTION}

Although extensive research efforts have been carried out to understand the ecological interrelationships of zebra mussels Dreissena polymorpha with other organisms in their habitats (Strayer 1999, Karatayev et al. 2002b), relatively little effort had been made to investigate the diversity, distribution, and significance of endosymbiotic organisms present within these mussels. This research imbalance was noted in a review of the literature on zebra mussel parasites (Molloy et al. 1997) and is currently being addressed by a network of over a dozen scientists from Europe and North America as a project of the Inter- national Research Consortium on Molluscan Symbionts (IRCOMS; http://www.nysm.nysed.gov/ircoms/). The present paper is a product of this effort by IRCOMS and presents the description of Ophryoglena hemophaga n. sp., an ophryoglenine ciliate (order Hymenostomatida, suborder Ophryoglenina) that feeds, at least in part, on blood cells within digestive gland lumina of zebra mussels. Stages in the life cycle are characterized, including the parasitic trophont, emerging protomont, encysted tomont, and infective theront. Although Ophryoglena spp. have previously been recorded as parasites of various invertebrates, $O$. hemophaga represents the first parasitic species to be described from a molluscan host. 


\section{MATERIALS AND METHODS}

A Dreissena polymorpha population infected with ophryoglenid ciliates (authors' unpubl. data) was sampled on August 21, 2000, and June 22, 2004, from Hollandsch Diep, a freshwater lake in the dammed estuary of the Rhine River near Noordschans, The Netherlands. Mussels were dissected to obtain trophonts for slide preparation and to conduct laboratory rearing experiments to characterize the life cycle.

To obtain morphological measurements, some of the trophonts were fixed in Bouin's fluid, and permanent microscope slides were prepared using the quantitative protargol stain (Montagnes \& Lynn 1993). Cells oriented roughly parallel to the plane of the slide were measured, and where possible, cell length, maximum cell width, macronuclear length, maximum macronuclear width, number of bipolar somatic kineties, oral cavity length and width, and length of the organelle of Lieberkühn were recorded.

To determine the number and position of contractile vacuoles, live trophonts were placed in a drop of unchlorinated tap water on a glass slide and viewed by microscope $(450 \times)$. Water was withdrawn from under the coverslip until the ciliate's movement was impeded and contraction and swelling of the contractile vacuoles could be observed.

For examination of the contents of digestive vacuoles within the ciliate cytoplasm, other trophonts were processed for permanent thin-section microscope slides by immersion in $2 \%$ glutaraldehyde (Grade I, Sigma) in $0.025 \mathrm{M}$ sodium cacodylate buffer ( $\mathrm{pH} 7.4$ ) for $90 \mathrm{~min}$ at $4^{\circ} \mathrm{C}$. After centrifugation at $200 \times g$, the cell pellets were rinsed in buffer solution $(0.05 \mathrm{M})$ and post-fixed with $1 \%$ osmium tetroxide (Sigma) buffered with sodium cacodylate. To facilitate manipulations, the cells were first embedded in agar. Following their dehydration through graded alcohol, they were embedded in EponAraldite (Sigma). Semi-thin $(1 \mu \mathrm{m})$ sections were cut with a diamond knife on an LKB Ultratom V ultramicrotome, stained with toluidine blue, and observed with an Olympus light microscope $(1000 \times)$.

To investigate the free-living phase of the life cycle, live mussels were held individually and emerging protomonts $(n=33)$ were subsequently observed for cyst formation and theront release. Similar experiments were also conducted to determine if large trophonts ( $\mathrm{n}=35$ ), which were removed from mussels by dissection, could also successfully encyst and produce theronts. These life cycle experiments were conducted in glass dishes holding unchlorinated tap water at ambient room temperature $\left(20 \pm 3^{\circ} \mathrm{C}\right)$. During these experiments, the phototatic orientation of life stages was investigated. As in similar ciliate phototactic experiments (Kuhlmann 1998a), a unidirectional, white light stimulus (in this case, a dissection scope illuminator) was supplied to the side of a glass dish, and cell motion was observed. Cells swimming horizontally across the glass dish toward or away from the light source were considered positively and negatively phototactic, respectively.

\section{RESULTS}

\section{Trophonts}

During dissection, trophonts were recorded only from the lumina of the digestive gland. When released into the dissection dish water, some exhibited slightly positive phototaxis, swimming toward the light source located at the side of the dish. Prevalence of infection was ca. $95 \%$ and most mussels had dozens of ciliates. After staining, trophonts were ovoid to elongate (Figs. $1 \& 2$ ) and had a mean \pm SD (range, sample size) number of somatic kineties of $57.5 \pm 3.5$ (50 to $62, \mathrm{n}=$ 11). Some of these ciliary rows curved to the right anterior to the oral region before abutting those of the left side. Other measurements of stained trophonts were: somatic length $=153.5 \pm 48.6 \mu \mathrm{m}(96.5$ to $288.0, \mathrm{n}=43)$; somatic width $=66.5 \pm 16.2 \mu \mathrm{m}(41.8$ to $103.7, \mathrm{n}=43)$; macronuclear length $=51.7 \pm 7.0 \mu \mathrm{m}(41.4$ to $64.8, \mathrm{n}=$ 20); macronuclear width $=11.7 \pm 4.2 \mu \mathrm{m}$ (6.3 to 18.0, $\mathrm{n}=20)$; oral cavity length $=13.2 \pm 2.1 \mu \mathrm{m}$ (10.8 to 18.0 , $\mathrm{n}=9)$; oral cavity width $=9.6 \pm 1.5 \mu \mathrm{m}(8.1$ to $11.7, \mathrm{n}=$ 10). Depending on the orientation of the ciliate, its watchglass-shaped organelle of Lieberkühn was sometimes visible (Figs. $1 \& 3$ ) and was $11.2 \pm 0.4 \mu \mathrm{m}$ (11.0 to $11.7, \mathrm{n}=3$ ) in diameter. The elongate macronucleus was often located anteriorly in trophonts (Figs. 1 \& 2) and was accompanied by at least one spherical micronucleus. The trophont did not have a caudal cilium. Semi-thin sections revealed that the cytoplasm was filled with digestive vacuoles, many of which contained clearly recognizable mussel hemocytes (Fig. 4). These hemocytes contained dark-staining nuclei and had cytoplasm sometimes filled with granular material typical of zebra mussel granulocytes or hyalinocytes (Giamberini et al. 1996). Trophonts contained a single tract of contractile vacuoles arranged longitudinally along the body length, and in some trophonts at least 6 contractile vacuoles were sometimes visible (Figs. $5 \& 6$ ). No pattern or sequence in the contraction of these vacuoles was apparent.

\section{Protomonts and tomonts}

Protomonts emerging from their hosts were negatively phototactic moving across the glass dish away from the 

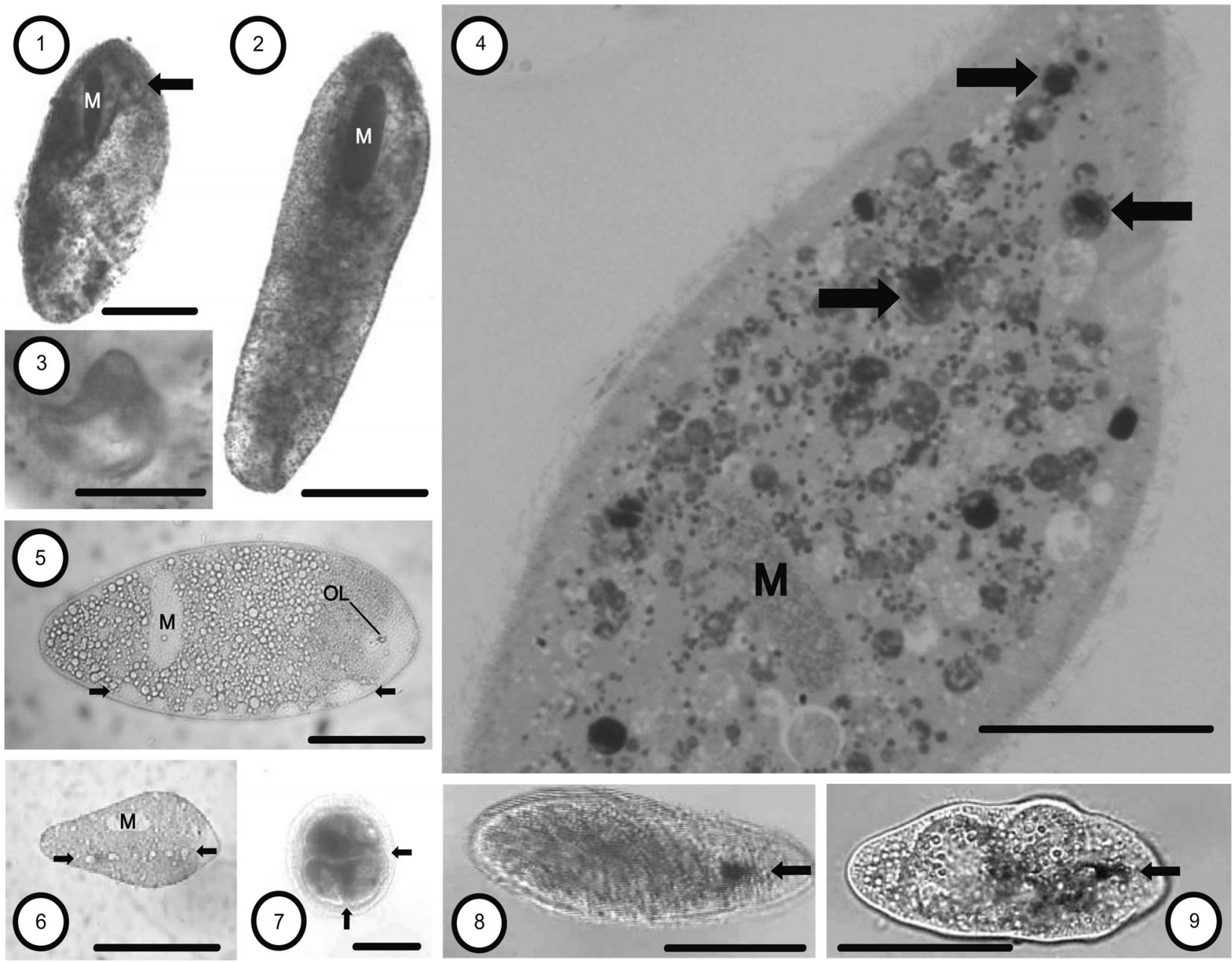

Figs. 1 to 9. Ophryoglena hemophaga n. sp. from Dreissena polymorpha. Photomicrographs of the ciliate parasite of the zebra mussel. (M) Macronucleus; (OL) organelle of Lieberkühn. Fig. 1. Ovoid trophont with prominent organelle of Lieberkühn (arrow) and elongate dark-staining macronucleus in anterior, Protargol stain. Scale bar $=50 \mu \mathrm{m}$. Fig. 2. Elongate trophont with elongate dark-staining macronucleus in anterior, Protargol stain. Scale bar $=50 \mu \mathrm{m}$. Fig. 3. Organelle of Lieberkühn, Protargol stain. Scale bar $=10 \mu \mathrm{m}$. Fig. 4. Semi-thin section of trophont revealing cytoplasm filled with digestive vacuoles, many of which contain mussel hemocytes in early stages of digestion (arrows), toluidine blue stain. Scale bar $=20 \mu \mathrm{m}$. Fig. 5. Living trophont with expanded contractile vacuoles visible (between arrows) at periphery of cell, unstained water mount. Scale bar $=50 \mu \mathrm{m}$. Fig. 6 . Living trophont with expanded contractile vacuoles visible (between arrows) near middle of cell, unstained water mount. Scale bar $=125 \mu \mathrm{m}$. Fig. 7. Living tomont with prominent planes of cell division (arrows), unstained water mount. Scale bar $=50 \mu \mathrm{m}$. Figs. 8 \& 9. Living theronts were elongate and possessed a single, dark spot anteriorly (dark arrows), unstained water mounts. Scale bars $=50 \mu \mathrm{m}$. Fig. 8. Theront with typical smooth outline. Fig. 9. Some theronts had an uneven outline, due to the presence of large, apparently fluid-filled vacuoles which were judged to be artifacts of microscopic observation

direction of light. During trials to observe tomont formation, both protomonts and dissection-derived trophonts swam for ca. 4 to $24 \mathrm{~h}$ before settling to the bottom of the dish. Before their actual attachment, however, they often hovered over a location for several hours, moving horizontally and vertically in short erratic tumbling bursts. During the time between their emergence and attachment, their shape became progressively rounder. A clear mucous cyst envelope in the shape of a dome was secreted by each tomont, and the thickness of this dome was typically about half the tomont's diameter. This mucous cyst envelope was so transparent that it was only observable when detritus settled on its exterior surface. The live tomont cell per se (without mucous cyst envelope) had a diameter of $119.2 \pm 26.9 \mu \mathrm{m}$ (50.0 to 150.0, $\mathrm{n}=13$ ), and similar to all other developmental stages in the life cycle was opaque white. As mitotic division progressed (Fig. 7), tomonts remained firmly attached (i.e. they could not be dislodged from the dish bottom by water currents from a micropipette). 


\section{Theronts}

Five tomonts successfully produced theronts. Four and 6 theronts emerged, respectively, from 2 of the tomonts obtained from dissection-derived trophonts, and 2, 4, and 8 theronts were produced, respectively, by 3 of the tomonts derived from protomonts. These theront numbers were consistent with 1 to 3 cell divisions during tomitogenesis. Living theronts were elongate cells, with length and width, respectively, of $121.6 \pm 14.6 \mu \mathrm{m}(96.0$ to $131.0, \mathrm{n}=5)$ and $47.8 \pm 5.5 \mu \mathrm{m}$ (38.0 to $51.0, \mathrm{n}=5$ ). Although most theronts were smooth in outline (Fig. 8), others had a more uneven shape due to the presence of large, apparently fluidfilled vacuoles (Fig. 9). Theronts exhibited a strong positive phototaxis swimming in a very pronounced fashion horizontally across the glass dish toward the direction of the light. All possessed a single, dark spot anteriorly (Fig. 8 \& 9). These spots appeared shortly before theront emergence and were clearly visible inside the tomont. Theronts emerged ca. 36 to $48 \mathrm{~h}$ after tomont encystment. No attempt was made to test if theronts could infect zebra mussels, and all died within $24 \mathrm{~h}$ of emergence.

\section{DISCUSSION}

\section{Taxonomy}

There have been over 40 species of ciliates assigned to the genus Ophryoglena. Kahl (1931) provided a key to Ophryoglena spp. and synonymized several species. Mugard (1949) produced the most recent synopsis of the genus and established strict criteria for inclusion of historical descriptions, emphasizing that features of the life cycle and the organelle of Lieberkühn should be clearly described. Mugard (1949) recognized 8 valid species of which 6 were newly described, discussed 9 doubtful or 'false' species, and synonymized 4 species. Subsequently, 11 new species of Ophryoglena have been described: $O$. monophthalma by Gelei (1950), O. hypertrophica by Savoie (1961), O. singularis by Canella \& Trincas (1961), O. faurei by Savoie (1962a), O. mugardi by Savoie (1962b), O. bacterocaryon by Roque, de Puytorac \& Savoie (1965); O. catenula by Savoie (1966); O. gelifera by Roque \& Savoie (1966), O. mucosa by Roque \& Savoie (1966), O. multimicronucleata by Roque \& Savoie (1966), and O. brachioni by Li (1993). Gaino \& Rebora (2000) described an Ophryoglena sp. from the ephemeropteran Caenis luctuosa, which may be related to O. collini.

The characters distinguishing species of Ophryoglena are related to aspects of the life cycle, especially the character of the cyst and cyst envelope, the size of the trophont and theront, the shape and size of the macronucleus, the shape, size, and number of micronuclei, the number of somatic kineties, the typical number of cell divisions as a tomont, the number and position of contractile vacuoles and their pores, the habitat in which they are found (e.g. freshwater, marine), and whether they are parasitic or opportunistic histophages. Descriptions since Mugard (1949) have generally mentioned most of these characters, although accurate counts of the number of somatic kineties are extremely difficult to make on Ophryoglena species. Comparison of the descriptions indicates that the following 'characters' can reliably separate many of the species: type of division by the tomont; number and position of contractile vacuoles; shape and size of the macronucleus; size of the trophont; number of somatic kineties; size of the cyst/ tomont, and nature of the cyst envelope. We have used these characters to assess the taxonomic position of our Ophryoglena species from Dreissena polymorpha.

Ophryoglena catenula is the only species whose tomonts form chains of tomites prior to cell separation (Savoie 1966) (Table 1). All other species divide within a cyst and in several successive complete divisions. The remaining species can be placed into 3 groups on the basis of their contractile vacuole $(\mathrm{CV})$ character: (1) 1 typically equatorial $\mathrm{CV}_{\text {; }}$ (2) $2 \mathrm{CVs}$, typically anterior and posterior to the equator; and (3) multiple CVs (Table 1).

Since the Ophryoglena sp. from Dreissena polymorpha has multiple CVs, it is closest to Ophryoglena intestinalis and O. pyriformis - the only described species of Ophryoglena with multiple CVs (Table 1). In both of these latter species, however, the CVs are scattered throughout the cell (Rossolimo 1926), whereas the CVs are arranged longitudinally in a single tract in the Ophryoglena sp. from D. polymorpha (Figs. $5 \& 6$ ).

Another distinguishing feature of the Ophryoglena sp. from Dreissena polymorpha is the low number of somatic kineties (i.e. 50 to 62 ) in the trophont. Thus, we believe that the Ophryoglena sp. from D. polymorpha is a new species, which we name $O$. hemophaga n. sp., and which we describe as follows.

\section{Ophryoglena hemophaga n. sp.}

Diagnosis. Stained trophont 96 to $288 \mu \mathrm{m}$ in length with 50 to 62 somatic kineties; live tomont 50 to $150 \mu \mathrm{m}$ in diameter producing a clear mucous cyst envelope whose thickness is approximately half of the tomont diameter; contains a single tract of multiple contractile vacuoles arranged longitudinally along the body length; found in the lumina of the digestive gland of Dreissena polymorpha. 
Table 1. Diagnostic features of valid species of the genus Ophryoglena. NS: not stated in publication

\begin{tabular}{|c|c|c|c|c|}
\hline Ophryoglena sp. & $\begin{array}{l}\text { Approx. number } \\
\text { of somatic } \\
\text { kineties }\end{array}$ & $\begin{array}{l}\text { Number of } \\
\text { contractile } \\
\text { vacuoles }\end{array}$ & Other diagnostic features & Source \\
\hline O. atra & 200 & 1 & Ovoid macronucleus & Mugard (1949) \\
\hline O. bacterocaryon & $200-205$ & 2 & Several elongate micronuclei & Roque et al. (1965) \\
\hline O. brachioni & NS & 1 & $\begin{array}{l}\text { Parasite of the rotifer Brachionus } \\
\text { theront and trophont with caudal cilia }\end{array}$ & Li (1993) \\
\hline O. catenula & NS & NS & Tomont divides in chains & Savoie (1966) \\
\hline O. collini & NS & 2 & $\begin{array}{l}\text { Parasite of ephemerid larvae } \\
\text { of Baetis }\end{array}$ & Lichtenstein (1921) \\
\hline O. faurei & $240-260$ & 2 & Flat, thin macronucleus & Savoie (1962a) \\
\hline O. flava & 300 & 2 & Large, foliaceous macronucleus & Mugard (1949) \\
\hline O. gelifera & 180 & 1 & Abundant clear jelly cyst wall & Roque \& Savoie (1966) \\
\hline O. hemophaga n. sp. & $50-62$ & Multiple & $\begin{array}{l}\text { 50-62 somatic kineties, thick } \\
\text { clear cyst wall, parasite of } \\
\text { Dreissena polymorpha }\end{array}$ & This study \\
\hline O. hypertrophica & $220-264^{\mathrm{a}}$ & 2 & Elliptical, flat macronucleus & Savoie (1961) \\
\hline O. intestinalis & NS & Multiple & $\begin{array}{l}\text { Parasite of turbellarian flatworm } \\
\text { Dicotylus }\end{array}$ & Rossolimo (1926) \\
\hline O. media & 350 & 2 & Flattened, discoidal macronucleus & Mugard (1949) \\
\hline O. monophthalma & 300 & 2 & $\begin{array}{l}\text { Elongated, spindle-shaped } \\
\text { trophont }\end{array}$ & Gelei (1950) \\
\hline O. mucifera & 315 & 2 & Very thick, mucous cyst wall & Mugard (1949) \\
\hline O. mucosa & 105 & 1 & Thick, mucous cyst wall & Roque \& Savoie (1966) \\
\hline O. mugardi & 100 & 2 & 2 micronuclei & Savoie $(1962 b)$ \\
\hline O. multimicronucleata & $110-115$ & 2 & $\begin{array}{l}\text { 5-6 micronuclei, elongate } \\
\text { macronucleus }\end{array}$ & Roque \& Savoie (1966) \\
\hline O. octavia & 160 & 2 & Flat, elongate macronucleus & Mugard (1949) \\
\hline O. parasitica & NS & 2 & $\begin{array}{l}\text { Parasite of the turbellarian } \\
\text { flatworm Dendrocoelum }\end{array}$ & André (1909) \\
\hline O. pectans & 300 & 1 & $\begin{array}{l}\text { Thick, mucous cyst wall, pointed } \\
\text { theront }\end{array}$ & Mugard (1949) \\
\hline O. polymicrocaryon & 350 & 2 & $\begin{array}{l}2-7 \text { micronuclei, discoid } \\
\text { macronucleus }\end{array}$ & Mugard (1949) \\
\hline O. pyriformis & NS & Multiple & $\begin{array}{l}\text { Parasite of turbellarian flatworms } \\
\text { Planaria and Sorocoelis }\end{array}$ & Rossolimo (1926) \\
\hline O. rhabdocaryon & NS & 2 & $\begin{array}{l}\text { 6-7 micronuclei, large, } \\
\text { flat macronucleus }\end{array}$ & Mugard (1949) \\
\hline O. singularis & $140-150$ & 2 & $\begin{array}{l}2 \text { micronuclei, elongate } \\
\text { macronucleus }\end{array}$ & Canella \& Trincas (1961) \\
\hline
\end{tabular}

Description. Ovoid to elongate Ophryoglena found in the digestive gland of Dreissena polymorpha. Stained trophont is 96 to $288 \mu \mathrm{m}$ long, 42 to $104 \mu \mathrm{m}$ in maximum width, and has ca. 50 to 62 somatic kineties, and an organelle of Lieberkühn 11.0 to $11.7 \mu \mathrm{m}$ in diameter. The elongate macronucleus is 41 to $65 \mu \mathrm{m}$ in length, 6 to18 $\mu \mathrm{m}$ in maximum width, and is accompanied by at least 1 spherical micronucleus. Live trophonts have a single tract of multiple contractile vacuoles arranged longitudinally along the body length. Live tomonts are spherical, 50 to $150 \mu \mathrm{m}$ in diameter, and secrete a clear, colorless mucous layer about $60 \mu \mathrm{m}$ in thickness. Live theronts are elongate,
96 to $131 \mu \mathrm{m}$ in length by 38 to $51 \mu \mathrm{m}$ in maximum width, and emerge after 1 to 3 cell divisions taking 36 to $48 \mathrm{~h}$ at $20 \pm 3^{\circ} \mathrm{C}$.

Etymology. The species name, hemophaga, is based on the presence of zebra mussel hemocytes in digestive vacuoles within the ciliate cytoplasm.

Type locality. Specimens were obtained from the Hollandsch Diep near Noordschans, The Netherlands $\left(51^{\circ} 40^{\prime} 60^{\prime \prime} \mathrm{N}, 4^{\circ} 31^{\prime} 60^{\prime \prime} \mathrm{E}\right)$.

Type slide. One protargol-stained slide has been deposited in the International Protozoan Type Slide Collection housed at The Smithsonian Institution, Museum of Natural History (Washington, DC, USA). 


\section{Life cycle}

As is typical of ciliates in the suborder Ophryoglenina, Ophryoglena hemophaga exhibits a polymorphic life history with cystment and reproduction by palintomy. This was evident from our laboratory tomitogenesis experiments. However, only $6 \%(2 / 35)$ and $9 \%$ (3/33), respectively, of the trophonts and protomonts used in these experiments produced viable theronts. It is understandable that tomitogenesis might not have been successful when trying to artificially induce it (i.e. using trophonts obtained by dissection), but the similarly low success rate with protomonts was unexpected. Use of natural waters, rather than unchlorinated tap water, may have increased the chances of successful theront development.

\section{Phototaxis}

Similar patterns of photo-orientation have previously been observed in laboratory experiments for several Ophryoglena spp., with ciliates before and after food uptake being, respectively, positively and negatively phototactic (Kuhlmann 1998a,b, Cadetti et al. 2000). Kuhlmann (1998a) provided evidence that the organelle of Lieberkühn plays an important role in this type of photo-orientation, probably functioning as a direction-sensitive light detector.

We hypothesize that the negative phototaxis of protomonts of Ophryoglena hemophaga is likely beneficial for the species. In the benthic habitat of zebra mussels, moving away from light probably increases the chance of coming into contact with a substrate for attachment. The negative phototaxis of protomonts also probably aids in their staying near their host zebra mussel population rather than being carried away by water currents. The positive phototaxis of theronts likely increases their opportunities for host contact, since zebra mussels actively filter the water column.

\section{Reports of ophryoglenids in zebra mussels}

There are previous reports of ophryoglenid ciliates within zebra mussel organs. Molloy et al. (1997) reviewed records of undescribed ophryoglenid species observed in the digestive gland of European Dreissena polymorpha populations. More recently, observations of an Ophryoglena sp. in the digestive gland of $D$. polymorpha have been reported by Karatayev et al. (2000, 2002a, 2003) from Belarus and by Fokin et al. (2003) from Germany, The Netherlands, and Russia. There is extensive histological evidence that these lat- ter ophryoglenid populations also ingest zebra mussel blood cells (authors' unpubl. data), and efforts are underway to determine if they are O. hemophaga.

Ophryoglenid ciliates have also previously been reported from the mantle cavity of zebra mussels. An Ophryoglena sp. was frequently found by Raabe (1966) in the mantle cavity of Dreissena in Lake Ohrid (Macedonia). More recently, Toews et al. (1993) observed Ophryoglena inside 'the shells' (i.e. mantle cavity) of living and dead D. polymorpha from Lake Erie (Canada). Since neither Raabe (1966) nor Toews et al. (1993) reported these Ophryoglena from the digestive gland or within any other organ, there is no evidence that these ophryoglenids were parasitic.

Most Ophryoglena spp. are opportunistic histophages, feeding on the tissues of wounded, moribund, or decaying bodies of aquatic or edaphytic metazoa (Corliss 1979). In addition to O. hemophaga, 5 other species in the family Ophryoglenidae have been described as parasitic (Table 1). Since O. hemophaga represents the first species to be described from a molluscan host, our observations suggest that $O$. hemophaga is an obligate and host-specific parasite of zebra mussels. The ingestion of blood cells by $O$. hemophaga is evidence of their parasitic nature, but the level of their pathogenicity remains to be determined. Hemocytes are likely ingested following their migration through epithelial cells into digestive gland lumina, i.e. diapedesis (Cheng 1981).

Acknowledgements. Special thanks to the crew of the 'De Nes' exploring vessel and A. bij de Vaate (Institute for Inland Water Management and Waste Water Treatment, The Netherlands) for assistance in mussel collection, A. Meyer (Laboratoire Ecotoxicité et Santé Environnementale, Université Paul Verlaine-Metz, France) for semi-thin slide preparation, and M. Strueder-Kypke (Department of Zoology, University of Guelph, Canada) for protargol slide preparation. Many thanks also to J. and S. Kruger (Cossayuna, New York, USA) for providing accommodations during manuscript preparation. This research was funded in part by travel grants from the Université Paul Verlaine-Metz to D.P.M. and L.G.

\section{LITERATURE CITED}

André E (1909) Sur un nouvel infusoire parasite des Dendrocoeles (Ophryoglena parasitica n. sp.). Rev Suisse Zool $17: 273-280$

Cadetti L, Marroni F, Marangoni R, Kuhlmann HW, Gioffré D, Colombetti G (2000) Phototaxis in the ciliated protozoan Ophryoglena flava: dose-effect curves and action spectrum determination. J Photochem Photobiol B Biol 57: $41-50$

Canella IR, Trincas L (1961) Ciclo vitale e nucleare di Ophryoglena singularis sp. n. (Ciliata, Holotricha, Hymenostomata): l'estrusione di cromatina dal macronucleo e il suo problematico significato funzionale. Pubbl del Civico Museo di Storia Naturale di Ferrara 5:1-44 (with English abstract) 
Cheng TC (1981) Bivalves. In: Ratcliffe NA, Rowley AF (eds) Invertebrate blood cells. Academic Press, London, p 233-300

Corliss JO (1979) The ciliated protozoa: characterization, classification, and guide to the literature. Pergamon Press, London

Fokin SI, Giamberini L, Molloy DP, bij de Vaate A (2003) Bacterial endocytobionts within endosymbiotic ciliates in Dreissena polymorpha (Lamellibranchia: Mollusca). Acta Protozool 42:31-39

Gaino E, Rebora M (2000) Ophryoglena sp. (Ciliata: Oligohymenophora) in Caenis luctuosa (Ephemeroptera: Caenidae). Acta Protozool 39:225-231

Gelei J (1950) A peculiar Ciliata: Ophryoglena monophthalma n. sp. Ann Biol Univ Szeged 1:237-242 (in Hungarian)

Giamberini L, Auffret M, Pihan JC (1996) Haemocytes of the freshwater mussel, Dreissena polymorpha Pallas: cytology, cytochemistry and X-ray microanalysis. J Molluscan Stud 62:367-379

Kahl A (1931) Urtiere oder Protozoa. I: Wimpertiere oder Ciliata (Infusoria). 2. Holotricha. (ausser den im 1. Teil behandelten Prostomata). In: Dahl F (ed) Die Tierwelt Deutschlands. G. Fischer, Jena, p 181-398 and plate 21

Karatayev AY, Burlakova LE, Molloy DP, Volkova LK (2000) Endosymbionts of Dreissena polymorpha (Pallas) in Belarus. Int Rev Hydrobiol 85:543-559

Karatayev AY, Burlakova LE, Molloy DP, Volkova LK, Volosyuk VV (2002a) Field and laboratory studies of Ophryoglena sp. (Ciliata: Ophryoglenidae) infection in zebra mussels, Dreissena polymorpha (Bivalvia: Dreissenidae). J Invertebr Pathol 79:80-85

Karatayev AY, Burlakova LE, Padilla DK (2002b) Impacts of zebra mussels on aquatic communities and their role as ecosystem engineers. In: Leppäkoski E, Gollasch S, Olenin $\mathrm{S}$ (eds) Invasive aquatic species of Europe: distribution, impacts and management. Kluwer Academic Publishers, Boston, MA, p 433-446

Karatayev AY, Mastitsky SE, Burlakova LE, Molloy DP, Vezhnovets GG (2003) Seasonal dynamics of endosymbiotic ciliates and nematodes in Dreissena polymorpha. J Invertebr Pathol 83:73-82

Kuhlmann HW (1998a) Do phototactic ciliates make use of directional antennas to track the direction of light? Eur J Protistol 34:244-253

Kuhlmann HW (1998b) Photomovements in ciliated protozoa. Naturwissenschaften 85:143-154

Li L (1993) Ophryoglena brachioni sp. nov. (Ciliophora, Ophryoglenidae) and its life cycle. Oceanol Limnol Sin 24:234-241 (in Chinese with English abstract)

Editorial responsibility: Albert Sparks,

Seattle, Washington, USA
Lichtenstein JL (1921) Ophryoglena collini, n. sp., parasite coelomique des larves d'ephémères. C R Seances Soc Biol Paris 85:794-796

Molloy DP, Karatayev AY, Burlakova LE, Kurandina DP, Laruelle F (1997) Natural enemies of zebra mussels: predators, parasites, and ecological competitors. Rev Fish Sci 5:27-97

Montagnes DJS, Lynn DH (1993) A quantitative protargol stain (QPS) for ciliates and other protists. In: Kemp PF, Sherr BF, Sherr EB, Cole JJ (eds) Handbook of methods in aquatic microbial ecology. Lewis Publishers, Boca Raton, FL p 229-240

Mugard H (1949) Contribution a l'étude des infusoires hymenostomes histiophages. Ann Sci Nat Zool (Ser 11) 10(1948):171-268

Raabe Z (1966) The parasitic ciliates of Dreissensia polymorpha and other Bivalvia in the Ohrid Lake. Acta Protozool 4:1-14

Roque M, Savoie A (1966) Trois espèces nouvelles d'ophryoglènes: O. gelifera, n. sp., O. mucosa, n. sp., O. multimicronucleata, n. sp. (Ciliés Holotriches Péniculiens). J Protozool 13:12-20 (with English abstract)

Roque M, de Puytorac P, Savoie A (1965) Groupement des protistologues de langue française: Ophryoglena bacterocaryon sp. nov., cilié, holotriche, péniculien (cytologie, ultrastructure, cycle). Arch Zool Exp Gen 105: 309-394.

Rossolimo LL (1926) Parasitische Infusorien aus dem BaikalSee. Arch Protistenkd 54:468-509 + plates 26 \& 27

Savoie A (1961) Ophryoglena hypertrophica n. sp. (Ciliata Hymenostomatida). J Protozool 8:324-334 (with English abstract)

Savoie A (1962a) Ophryoglena faurei n. sp. (Ciliata Hymenostomatida Ophryoglenidae). Cycles de reproduction. J Protozool 9:427-434 (with English abstract)

Savoie A (1962b) Ophryoglena mugardi n. sp. (Ciliata Hymenostomatida Ophryoglenidae). Cycles de reproduction. J Protozool 9:296-303 (with English abstract)

Savoie A (1966) Ophryoglena catenula nov. sp., Ophryoglène à tomitogenèse caténulaire. Ann Stn Biol Besse-enChandesse 1:67-69

Strayer DL (1999) Effects of alien species on freshwater mollusks in North America. J North Am Benthol Soc 18: $74-98$

Toews S, Beverley-Burton M, Lawrimore T (1993) Helminth and protist parasites of zebra mussels, Dreissena polymorpha (Pallas, 1771), in the Great Lakes region of southwestern Ontario, with comments on associated bacteria. Can J Zool 71:1763-1766

Submitted: April 12, 2004; Accepted: January 17, 2005

Proofs received from author(s): July 1, 2005 